\title{
Hand hygiene: nurses' adherence after training
}

\author{
Higiene das mãos - adesão dos enfermeiros após processo formativo \\ Higiene de las manos - adhesión de los enfermeros tras el proceso formativo
}

\section{João Manuel Garcia do Nascimento Graveto', Rita Isabel Figueira Rebola", Elisabete Amado Fernandes", Paulo Jorge dos Santos Costa'}

\author{
'Escola Superior de Enfermagem de Coimbra. Coimbra, Portugal. \\ "Centro Hospitalar e Universitário de Coimbra. Coimbra, Portugal.
}

How to cite this article:

Graveto JMGN, Rebola R, Fernandes E, Costa PS. Hand hygiene: nurses' adherence after training. Rev Bras Enferm [Internet]. 2018;71(3):1189-93. DOI: http://dx.doi.org/10.1590/0034-7167-2017-0239

\section{Submission: 03-31-2017_Approval: 05-23-2017}

\begin{abstract}
Objective: Hand hygiene plays a key role in the prevention of healthcare-associated infections. Therefore, this study aims to analyze nurses' adherence to hand hygiene and identify intervention strategies to improve this procedure. Method: Integrative literature review, using the Cochrane methodology, to answer the following question: "What is the level of effectiveness of training in improving nurses' adherence to hand hygiene?". Results: Studies show that nurses' adherence to hand hygiene has increased from $42.9 \%$ to $61.4 \%$ $(p<0.001)$, or even from $63 \%$ to $76 \%(p<0.005)$ after a specific training intervention. Conclusion: After training, nurses' adherence to hand hygiene improved, particularly when compared to the other professionals involved. Despite its simplicity, the implementation of a training program and its subsequent follow-up have a positive on nurses' attitudes and adherence to hand hygiene.
\end{abstract}

Descriptors: Hand Hygiene; Staff Development; Nurses; Infection Control; Infection.

\section{RESUMO}

Objectivos: A higienização das mãos é considerada uma medida preponderante na prevenção das Infeções Associadas aos Cuidados de Saúde. Deste modo, pretende-se conhecer a adesão dos enfermeiros ao procedimento e identificar estratégias de atuação de forma a aumentar a mesma. Método: Revisão integrativa de literatura, norteada por metodologia Cochrane, de modo a responder à questão "Em relação aos enfermeiros, qual a eficácia do processo formativo na adesão à higienização das mãos?". Resultados: estudos demonstram o aumento da adesão à higienização das mãos por parte dos enfermeiros de $42,9 \%$ para $61,4 \%$ após intervenção específica $(p<0,001)$ e ainda $63 \%$ versus $76 \%$, $(p<0,005)$. Conclusão: os processos formativos aumentam a adesão dos enfermeiros, sendo esse aumento mais significativo comparativamente às restantes classes profissionais envolvidas. O processo formativo e sua monitorização, apesar da simplicidade, continuam a ter um efeito positivo nas atitudes e na adesão dos enfermeiros à higienização das mãos.

Descritores: Higiene das Mãos; Desenvolvimento de Pessoal; Enfermeiras e Enfermeiros; Controle de Infecções; Infecção.

\section{RESUMEN}

Objetivo: La higienización de las manos se considera una medida preponderante para prevenir las Infecciones Asociadas a la Atención Sanitaria. De este modo, se pretende conocer la adhesión de los enfermeros al procedimiento e identificar estrategias de actuación con el fin de aumentar la higienización. Método: Revisión integradora de la literatura, orientada por la metodología Cochrane, para responder a la pregunta: «En relación a los enfermeros, ¿cuál es la eficacia del proceso formativo en la adhesión a la higienización de las manos?». Resultados: los estudios demuestran el aumento de la adhesión a la higienización de las manos por parte de los enfermeros, del $42,9 \%$ al $61,4 \%$ después de la intervención específica $(p<0,001)$ y también el $63 \%$ frente al $76 \%$ ( $p<0,005)$. Conclusión: los procesos formativos aumentan la adhesión de los enfermeros. Este aumento es más significativo en comparación con el resto de las clases profesionales involucradas. El proceso formativo y su monitorización, a pesar de la simplicidad, siguen teniendo un efecto positivo en las actitudes y la adhesión de los enfermeros a la higienización de las manos. Descriptores: Higiene de las Manos; Desarrollo del Personal; Enfermeras y Enfermeros; Control de Infecciones; Infección. 


\section{INTRODUCTION}

Healthcare-associated infections (HAIs) are a major problem in current care delivery settings. They can be caused by endogenous (present on the skin, nose, gastrointestinal tract, etc.) or exogenous infectious agents, with the healthcare professionals' hands being the most common transmission route ${ }^{(1)}$. Special attention should be given to this issue and nurses, as care providers, should give their important contribution to the prevention of these infections. Therefore, and because it is considered to be the first universal measure to control HAIs, hand hygiene should be constantly promoted $^{(2)}$.

It is estimated that hundreds of thousands of people are affected by preventable HAls each year. The multiple determinants of HAls are associated with a complex combination of gaps found in health-related policy, infrastructure, organization, and knowledge, as well as with professionals' inadequate practices and behaviors ${ }^{(3)}$. In Europe, HAls are responsible for 16 million extra days of hospital stay (ranging between 5 and 29.5 days), 37,000 attributable deaths, and at least 110,000 HAl-related deaths each year. In economic terms, estimates point to a loss of 7 billion euros in direct costs ${ }^{(1)}$. In addition, the costs associated with extended length of hospital stay have also increased, which can be explained by the costs associated with the implementation of infection prevention and control measures.

HAls can lead to increased length of hospital stay, co-morbidities in the long-term, antimicrobial resistance, and a significant economic impact on health institutions, patients, and families. Moreover, the analysis of HAl-related costs should take into account personal and family losses, given that a longer hospitalization affects the patient's physical and emotional well-being, family income, among other aspects ${ }^{(4)}$.

HAls occur during hospitalization, not being present at the time of hospital admission. It is common for inpatients to develop these complications, mainly in the urinary tract, surgical site, airways, and bloodstream. However, health professionals can also develop HAIs during their daily clinical activities ${ }^{(1)}$.

Therefore, health professionals should perform hand hygiene according to the "Five Moments" model proposed by the World Health Organization (WHO) in the WHO Guidelines on Hand Hygiene in Health Care ${ }^{(5)}$ : before touching a patient; before a clean/aseptic procedure; after body fluid exposure risk; after touching a patient; and after touching patient surroundings. Since microorganisms are mostly transmitted through health professionals' hands, hand hygiene is considered a key procedure for the prevention of HAls. Thus, guidelines are important to improve this process, set targets for controlling HAI risks, and train teams in the use of infection prevention measures.

In view of the above, health professionals' adherence to hand hygiene is of utmost importance, particularly following training on the topic. Despite the extensive discussion about nurses' knowledge on the importance of hand washing, it can be difficult to ensure proper adherence to this simple and affordable procedure. Therefore, the interest emerged to research on and discuss this topic in order to understand the reasons underlying health professionals' lack of adherence in some situations.

\section{OBJECTIVE}

Identifying nurses' level of adherence to hand hygiene, as well as intervention strategies to improve their adherence.

\section{METHOD}

This integrative literature review was conducted following Cochrane's PICOD strategy (Participants, Interventions, Comparisons, Outcomes, and Design), as shown in Chart 1. The following research question was formulated: "What is the level of effectiveness of training (I) in improving nurses' $(\mathrm{P}) \mathrm{ad}-$ herence to hand hygiene $(\mathrm{O})$ ?".

Inclusion and exclusion criteria were previously established and the search focused on recent studies which were relevant to the topic under analysis. The studies were selected using the investigator triangulation strategy. Since the purpose was to analyze health professionals' interventions with adult patients, all studies conducted in neonatal and pediatric units were excluded, as well studies that included nursing students in their population, studies that did not address the impact of training interventions on health professionals' adherence to hand hygiene and the monitoring of results, and studies that had no quantitative or qualitative research findings.

Chart 1 - Criteria for the formulation of the research question according to the $\mathrm{PI}(\mathrm{C}) \mathrm{O}(\mathrm{D})$ model (Participants, Interventions, Comparisons, Outcomes, and Design)

\begin{tabular}{|l|l|l|}
\hline \multicolumn{2}{|c|}{ PI(C)O(D) Method } & \\
\hline P (Participants) & Nurses & \\
\cline { 1 - 2 } I (Interventions) & Training & \multirow{2}{*}{$\begin{array}{c}\text { Keywords } \\
\text { hand washing, nurse; knowledge; adherence; } \\
\text { training; healthcare. }\end{array}$} \\
\hline O (Outcomes) & Adherence to hand hygiene & \\
\hline D (Design) & Qualitative or quantitative studies & \\
\hline
\end{tabular}




\section{RESULTS}

Out of the 40 studies found in the initial search, 14 were included after application of the exclusion criteria and removal of duplicates. After a more careful reading and analysis of the 14 articles, five articles were selected for being considered relevant to the topic under analysis (Chart 2).

Chart 2 - Description of the selected studies

\begin{tabular}{|c|c|}
\hline Ref. & Description of the study \\
\hline (6) & $\begin{array}{l}\text { Type of Study: Descriptive, cross-sectional, } \\
\text { interventional, prospective, analytical study. } \\
\text { Objectives: To identify health professionals' level } \\
\text { of knowledge and compliance with handwashing } \\
\text { procedures. Participants: Nurses and doctors working } \\
\text { in an intensive care unit. Results: Only } 61.2 \% \text { of } \\
\text { respondents knew the correct hand hygiene technique; } \\
50 \% \text { of nurses knew the correct hand washing } \\
\text { technique. Adherence to hand hygiene improved } \\
\text { from } 47 \% \text { before the intervention to } 55.7 \% \text { after the } \\
\text { intervention. }\end{array}$ \\
\hline (7) & $\begin{array}{l}\text { Type of Study: Cross-sectional, interventional, prospective, } \\
\text { analytical study. Objectives: To evaluate nurses' } \\
\text { handwashing behavior and knowledge before and after } \\
\text { a training program. Participants: } 200 \text { nurses from a } \\
\text { university hospital in Turkey. Results: After the training } \\
\text { program, nurses showed a significant increase in the } \\
\text { frequency of handwashing (from } 41.1 \% \text { to } 48.6 \% ; t=- \\
2.202 ; p=0.029 \text { ), the time spent in handwashing (from } \\
64.5 \% \text { to } 72.5 \% ; p=0.024 ; p<0.05 \text { ), the knowledge } \\
\text { (from } 36.9 \% \text { to } 46.3 \% ; t=-16.081 ; p<0.05 \text { ), and the } \\
\text { quality of the handwashing technique (from } 15.38 \% \text { to } \\
17.56 \% ; t=-10,874 ; p<0.05 \text { ). }\end{array}$ \\
\hline (8) & $\begin{array}{l}\text { Type of Study: Cross-sectional, observational study. } \\
\text { Objectives: To assess nurses and allied healthcare } \\
\text { workers' adherence to hand hygiene after a one-year } \\
\text { training intervention. Participants: Nurses and allied } \\
\text { healthcare workers. Results: Nurses' adherence to } \\
\text { hand hygiene was } 63 \% \text {; adherence was } 93 \% \text { after } \\
\text { patient contact and } 63 \% \text { before patient contact. } \\
\text { Participants showed an overall adherence of } 78 \% \text {, and } \\
\text { it was concluded that this behavior can be ensured by } \\
\text { continuous training. }\end{array}$ \\
\hline (9) & $\begin{array}{l}\text { Type of Study: Cross-sectional and interventional } \\
\text { prospective analytical study. Objectives: To investigate } \\
\text { factors associated with adherence to hand hygiene. } \\
\text { Participants: Health professionals from a private } \\
\text { hospital in Turkey. Results: Adherence to hand hygiene } \\
\text { was higher in trained doctors than in untrained } \\
\text { doctors before patient contact and after environment } \\
\text { contact }[48 \%(35 / 73) \text { versus } 82 \%(92 / 113) p<0.05 \\
\text { and } 23 \%(5 / 22) \text { versus } 76 \%(37 / 49) ; p<0.05 \\
\text { respectively].Trained allied health personnel showed } \\
\text { greater adherence to hand hygiene than untrained } \\
\text { ones before asepsis [20\% }(2 / 10) \text { versus } 73 \%(16 / 22) \text {; } \\
p<0.05] \text {. Adherence to hand hygiene was higher in } \\
\text { trained nurses than in untrained ones before patient } \\
\text { contact }[63 \% \text { (50/79) versus } 76 \%(37 / 49) ; p<0.05] \text {. } \\
\text { In addition, antiseptic solutions were used when hand } \\
\text { washing was not possible. }\end{array}$ \\
\hline
\end{tabular}

To be continued
Chart 2 (concluded)

\begin{tabular}{|l|l|}
\hline Ref. & $\begin{array}{l}\text { Description of the study } \\
\text { Type of Study: Interventional study. Objectives: To } \\
\text { determine the adherence to hand hygiene and its } \\
\text { effect on HAls in an intensive care unit in Kuwait. } \\
\text { Participants: Health professionals working at the } \\
\text { intensive care unit of a hospital. Results: Adherence } \\
\text { increased from } 42.9 \% \text { before the intervention to } 61.4 \% \\
\text { after the intervention ( } p<0.001) \text {. Nurses' adherence } \\
\text { increased from } 43.2 \% \text { to } 82.5 \%(p<0.001), \text { showing } \\
\text { a greater adherence than doctors and other health } \\
\text { professionals. There was a significant reduction in the } \\
\text { number of HAls, from } 37.2 \% \text { to } 15.1 \% \text {. }\end{array}$ \\
\hline
\end{tabular}

Note: HAls - Healthcare-Associated Infections

\section{DISCUSSION}

HAls are becoming increasingly common, which has heightened the interest in this topic over time ${ }^{(1-5)}$. According to the authors of the studies included in this review, health professionals' training has a direct impact on the adherence to hand hygiene ${ }^{(6-10)}$. Therefore, these studies have contributed to answering the research question.

The analyzed studies found an urgent need for intervention among health professionals in order to change their attitudes towards hand hygiene ${ }^{(2-5)}$. In each study, a training program was implemented with the purpose of assessing health professionals' adherence to hand hygiene, as well as the quality of hand hygiene, before and after the training program ${ }^{(6-10)}$. These programs consisted of multiple components, such as lectures on hand hygiene ${ }^{(6,10)}$; training sessions on hand hygiene and fight against HAIs ${ }^{(7,9)}$; preparation of booklets or flyers ${ }^{(7,10)}$; and display of posters about the topic in key locations ${ }^{(9-10)}$.

Four studies compared the adherence to and training in hand hygiene among different professional groups. In three of those studies, nurses were the professional group with higher levels of training in this procedure ${ }^{(6,9-10)}$, when compared to doctors, health technicians, and allied healthcare workers . However, one of the studies reported that, despite the higher levels of training, only $43 \%$ of nurses and $18 \%$ of health technicians had washed their hands during the observation period, which may suggest that the knowledge about a certain procedure does not, in itself, translate into best practices ${ }^{(6)}$.

On the other hand, in a study that compared nurses and allied healthcare workers, the adherence to hand hygiene was of $63 \%$ among nurses and $86.5 \%$ among allied healthcare workers ${ }^{(8)}$. Contrary to these results, one of the analyzed studies $^{(10)}$ found that adherence was higher among nurses $(50 \%)$ than among doctors (45\%) and other health professionals $(38.4 \%)$. Only one of the included studies focused on a single professional group: nurses ${ }^{(7)}$.

It should be noted that adherence to hand hygiene was higher among trained professionals than among untrained ones $(76 \%$ versus $63 \% ; p<0.005)$, and that antiseptic solutions were used when hand washing was not possible ${ }^{(9)}$.

In the same line of thought, other authors have also reported an increase in the adherence to hand hygiene from 
$42.9 \%$ before the intervention to $61.4 \%$ after the intervention $(p<0.001)$ among all health professionals, as well as a significant reduction in HAls, from $37.2 \%$ to $15.1 \%{ }^{(10)}$.

Some authors ${ }^{(8)}$ have analyzed the hand hygiene procedure ("five moments" for hand hygiene $\left.{ }^{(5)}\right)$. According to these studies, after the training program, adherence was higher in steps 3 and 4 (self-protection) ${ }^{(8-9)}$ and lower after aseptic procedures $^{(8)}$ and after touching patient surroundings ${ }^{(10)}$. Similarly, the authors of another study observed that only $47 \%$ of the professionals washed their hands before touching the patient and that $70 \%$ washed their hands after touching the patient ${ }^{(6)}$. These results may suggest that professionals perform hand hygiene due to personal safety concerns, which may explain the inconsistency found in the adherence to the procedure before and after touching the patient. However, it should be noted that the reasons why professionals perform this procedure should be further analyzed.

Three of the included studies have explored the reasons that compromise professionals' adherence and the quality of the procedure ${ }^{(6,8-9)}$. "Lack of time" $(41.4 \%)$ and "skin irritation" $(6.3 \%)$ were some of the reasons mentioned in one study ${ }^{(6)}$. In addition, the same study pointed out that several professionals worked below standard conditions during the observation periods. This reality was also reported in another study, which noted that the unavailability of materials in the work area, the high workload, and the shortage of nurses were barriers to professionals ${ }^{\prime}$ adherence ${ }^{(8)}$. Teker et al. ${ }^{(9)}$ listed multiple factors with the potential to influence these indicators, such as lack of training and experience; lack of feedback on inadequate performance; working in highly complex care units; inadequate staffing; lack of role models in the team; inadequate use of gloves; lack of knowledge about the importance of the procedure; inadequate time management; planning of care without accounting for the time necessary for hand hygiene; lack of motivation at individual and institutional levels; lack of priority of hand hygiene at the institutional level; lack of performance rewards or sanctions; and lack of institutional guidelines.

Studies showed a growing concern of institutions with the provision of alcohol-based handrubs inside and outside of patients' rooms, at their bedside, and in common areas, in order to ensure easy access to them ${ }^{(8,10)}$. This concern was also evident in the increasing need to provide accessible and appropriate areas for hand hygiene ${ }^{(9)}$.

Interestingly, only one study reported a patient's concern about whether a health professional had washed his/her hands before the examination ${ }^{(6)}$. The lack of similar patient accounts in other studies may suggest that patients are not aware of the importance of this procedure during care delivery. Therefore, patients' perceptions of this reality should be further analyzed in order to increase patients' awareness and involvement in this procedure.

To sum up, all the included studies were consensual and presented complementing views about the positive effects of the implementation of training programs on the performance, quality, and knowledge about hand hygiene after the different interventions ${ }^{(6-10)}$. However, one study emphasized the importance of continuous training to maintain these behaviors $^{(8)}$.

\section{Limitations of the study}

One of the limitations of this review was the lack of research studies about the topic under analysis, particularly in the national context. Given its integrative nature, the selection of search descriptors, databases, and languages may have limited the final results.

\section{Contributions to Nursing and Health Policies}

The results of this integrative literature review contribute to the debate and research in this area. Health institutions should invest in the implementation, monitoring, and assessment of the existing training programs towards the prevention of HAls as a way of reducing healthcare-related costs and improving care quality. However, some health institutions lack professionals with specialized training and support infrastructures; hence, investment in this area is of utmost importance.

\section{CONCLUSION}

The analysis of the studies included in this integrative literature review on "Hand hygiene - nurses' adherence after training" allows concluding that the authors agree on the importance of hand hygiene in preventing the development of nosocomial infections during nursing care delivery.

Nevertheless, despite acknowledging the need for this key procedure, nurses showed inadequate hand hygiene techniques and adherence during their daily care routines. The reasons for this include the lack of adequate facilities for washing and drying hands inside the clinical areas, the lack of resources, the time factor, the existence of solutions of continuity in hands, and excessive workload.

Nursing professionals should continuously update and monitor their knowledge and transfer it into clinical practice. The importance of discussing this topic is consensual and universal among nurses as they are responsible for hand hygiene and raising awareness about the need for change, which is only possible through the delivery of quality care. In turn, quality can only be achieved through the implementation, training, and development of effective and adequate hand hygiene techniques.

Some measures are perfectly feasible, such as the implementation of standard infection control measures; a greater dissemination of the importance of hand hygiene through training actions and flyers/posters placed in strategic locations; and, in particular, each nurse's responsibility in ensuring a proper hand hygiene, which is consistent with good nursing practices. With these measures, healthcare-related costs and morbidity and mortality rates associated with HAls would be significantly reduced.

\section{FUNDING}

This study was financed by national funds through the Foundation for Science and Technology, I.P., within the scope of Project No. UID/DTP/00742/2013. 


\section{REFERENCES}

1. Allegranzi B, Nejad SB, Combescure C, Graafmans W, Attar H, Donaldson L, et al. Burden of endemic health-care-associated infection in developing countries: systematic review and meta-analysis. Lancet [Internet]. 2011 [cited 2017 Feb 15];377(9761):22841. Available from: http://www.thelancet.com/pdfs/journals/lancet/PIIS0140-6736(10)61458-4.pdf

2. Pires FV, Tipple AFV, Freitas LR, Souza ACS, Pereira MS. Moments for hand hygiene in Material and Sterilization Center. Rev Bras Enferm [Internet]. 2016 [cited 2017 Feb 15];69(3):511-5. Available from: http://www.scielo.br/pdf/reben/v69n3/en 0034-7167reben-69-03-0546.pdf

3. World Health Organization (WHO). Global Guidelines for the Prevention of Surgical Site Infection[Internet]. WHO Press: Geneva, Switzerland; 2016 [cited 2017 Feb 15]. Available from: http://www.who.int/gpsc/ssi-prevention-guidelines/en/

4. Damani N. Manual of Infection Prevention and Control. 3rd ed. United States of America: Oxford University Press; 2012.

5. World Health Organization. WHO Guidelines on Hand Hygiene in Health Care: first global patient safety challenge clean care is safer care[Internet]. WHO Press: Geneva, Switzerland. 2009 [cited 2017 Feb 15]. Available from: http://whqlibdoc.who.int/ publications/2009/9789241597906_eng.pdf

6. De Vita V, Weisburd G, Beltramino EBD. Conocimiento, actitudes y prácticas del personal de salud relacionados con el lavado de manos clinico en una unidad de cuidados intensivos. Rev Méd Rosario [Internet]. 2014 [cited 2017 Feb 15];80(1):105-16. Available from: http://www.circulomedicorosario.org/Upload/Directos/Revista/1a1e43De Vita Lavado de Manos.pdf

7. Erkan T, Findik UY, Tokuc B. Hand-washing behaviour and nurses' knowledge after a training programme. Int J Nurs Pract [Internet]. 2011 [cited 2017 Feb 15];17(5):464-9. Available from: http://onlinelibrary.wiley.com/doi/10.1111/j.1440-172X.2011.01957.x/pdf

8. Chavali S, Menon V, Shukla U. Hand hygiene compliance among healthcare workers in an accredited tertiary care hospital. Indian J Crit Care Med [Internet]. 2014 [cited 2017 Feb 15];18(10):689-93. Available from: doi:10.4103/0972-5229.142179

9. Teker B, Ogutlu A, Gozdas HT, Ruayercan S, Hacialioglu G, Karabay O. Factors affecting hand hygiene adherence at a private hospital in Turkey. Eurasian J Med [Internet]. 2015 [cited 2017 Feb 15];47(3):208-12. Available from: https://www.ncbi.nlm.nih. gov/pmc/articles/PMC4659524/pdf/eajm-47-3-208.pdf

10. Salama MF, Jamal WY, Mousa H Al, Al-AbdulGhani KA, Rotimi VO. The effect of hand hygiene compliance on hospital-acquired infections in an ICU setting in a Kuwaiti teaching hospital. J Infect Public Health [Internet]. 2013 [cited 2017 Feb 15];6(1):27-34. Available from: http://www.jiph.org/article/S1876-0341(12)00130-X/pdf 